\title{
Establishing a Simulation Centre in Karachi, Pakistan
}

\author{
Jacqueline Maria Dias* and Rukhsana W Zuberi \\ Faculty of Health Sciences, Pakistan \\ *Corresponding author: Jacqueline Maria Dias, Faculty of Health Sciences, Stadium Road, Karachi, Pakistan \\ Submission: 眥 February 15, 2018; Published: 眥 February 22, 2018
}

\section{What Problem Was Addressed?}

Health care professionals need to be adequately educated and trained to provide safe and competent care. Skills learning are an integral part of the training of health professionals. Simulation Centers provide the space and opportunity for health professions to make mistakes, practicing in a safe environment, thereby reducing risk and enhancing patient safety. The Aga Khan University (AKU) is committed to maintain high quality and pursue excellence in all its programs. Based on this premise, AKU envisioned a state-of-theart, multipurpose, multidisciplinary and multi-professional facility for doctors, nurses, dentists and allied health personnel to enhance cognitive, clinical, behavioral, communication and procedural skills. The latter range from small procedures to cutting-edge emergency and operative interventions and from team training to inter-professional education (IPE). The planning took a decade with conceptual transformation of a Skills Lab to a Skills Learning Centre to a Simulation Centre and finally to a Centre for Innovation in Medical Education (CIME), taking 'medicine' in the broadest sense. CIME was inaugurated on November 27, 2015.

\section{What Was Tried?}

User and Commissioning Groups were established representing Medicine, Nursing, Information-Technology, Dentistry, Biomedical Engineering, Marketing, Design-office, Finance, Security, Food Services, Facilities and Material Management. Site visits were undertaken to understand the design and operationalization of simulation centers around the world, and international advisors heading world renowned simulation centers were consulted. As the design brief received approval from AKU leadership, donor funding was sought. When construction began, committees for Policies, Utilization, Marketing, Faculty Development, Equipment, Human Resources, Budgeting, Information-Technology, Research, e-Health, and a Masters in Simulation Studies were established.
Until a Director was recruited, Interim and Co-Interim Directors were appointed. They requested each clinical department to nominate two faculty members interested in simulations and called them CIME Champions (CIMEC), and arranged funding for their development in 'simulation-based education (SBE).'

A Strategic Retreat was called inviting all CIME stakeholders to define the way forward. Groups were established, each chaired by a CIME-Champion: for integration of simulation across undergraduate and graduate curricula; to broaden and enhance simulationbased continuous professional development (CPD) across all health professions, including IPE and team training; research and industry; equipment; finance; and leadership development. Vendor based training was used to train all interested faculty in simulation. Lastly, a five-year faculty development plan was introduced not just to produce simulation-based educators, but also master-trainers and future leaders in Simulation. Opportunities were sought for receiving simulation based training locally, regionally and abroad [1].

\section{What Lessons Were Learned?}

The entire ten year journey was full of excitement and learning. One of the biggest lessons learnt was that although nearly all important steps should be initiated before the inauguration, for example, a Steering Committee to lay down guidelines, a Director for implementation, integration of simulation into curricula, marketing plans, and a financial model, certain steps should be taken years prior to initiation and are critical, which are faculty and curricular development for SBE.

\section{References}

1. Kim S, Hewitt W, Buis JA, Ross BK (2015) Creating the Infrastructure for a Successful Simulation Program. In: Palaganas, J, Maxworthy C, Epps CA, Mancini ME (Eds.), Defining Excellence in Simulation Program. Wolters Kluwer, Philadelphia, USA, pp. 66-89. 
Creative Commons Attribution 4.0

International License

For possible submissions Click Here

Your subsequent submission with Crimson Publishers will attain the below benefits

- High-level peer review and editorial services

- Freely accessible online immediately upon publication

- Authors retain the copyright to their work

- Licensing it under a Creative Commons license

- Visibility through different online platforms

- Global attainment for your research

- Article availability in different formats (Pdf, E-pub, Full Text)

- Endless customer service

- Reasonable Membership services

- Reprints availability upon request

- One step article tracking system 